DOI 10.33463/2712-7737.2019.01(1-3).2.084-098

Siryakov A. N., Abishev E. H.

Сиряков А. Н., Абишев Э. Х.

\title{
LEGISLATION ON EDUCATIONAL WORK WITH PRISONERS IN RUSSIA AND KAZAKHSTAN
}

\section{ЗАКОНОААТЕАЬСТВО О ВОСПИТАТЕАЬНОЙ РАБОТЕ С ОСУЖАЕННЫМИ К АИШЕНИЮ СВОБОАЫ В РОССИИ И КАЗАХСТАНЕ}

\begin{abstract}
In the desire to reform the penal system, separate countries of the Commonwealth of Independent States have made significant progress, substantially updating their legal framework. These also include the Republic of Kazakhstan. The study of the normative consolidation and organization of educational work with convicts under the Kazakhstan and Russian legislation and a questionnaire of practitioners revealed the advantages and disadvantages of regulatory support and law enforcement practice. This made it possible to outline further ways to improve the legal regulation of educational work with convicts in the direction of convergence with international standards. The penal legislation of the two countries largely coincides, but in Kazakhstan the issues of educational work find their legal consolidation not only at the level of the Penal code, but also in special acts. The advantages of Kazakhstan's legislation include: a clear definition of the tasks, directions, forms and methods of educational work; improvement of the mechanism of incentives and penalties application; determining the degree of behavior of convicts; involvement of the Probation Service in the provision of social and legal assistance to convicts preparing for the release; the presence of convicts among the subjects of educational work of voluntary organizations. Otherwise, the organization and conduct of educational work with convicts coincide. The basis of the organizational structure of the correctional institution is the unit, the heads of which are overloaded with the tasks not directly related to the implementation of the correctional process. Taking into account the experience of the Republic of Kazakhstan, it is proposed to amend the Penal code of the Russian Federation, in terms of the formulation of the concept of educational work through its tasks; clarification of norms relating to the directions, forms and methods of educational work. In the Provision about the units of prisoners in correctional institution, it is necessary to change the amount of duties for the head of the unit: establishing a ban (limitation) on the involvement of chiefs to implement unusual functions for them; the transfer to the category of rights the obligation to participate in inspections of the
\end{abstract}

(c) Siryakov А. N., Abishev E. Н., 2019
() Сиряков А. Н., Абишев Э. Х., 2019 
presence of persons held in a correctional institution, taking them to work (from work), their presence during searches, mealtime in the dining room, getting of parcels, transfer, sale of food and basic necessities, telephone conversations.

Keywords: educational work with convicted persons, penal legislation, Russian Federation, Republic of Kazakhstan.

Аннотация. В стремлении реформирования системы исполнения уголовных наказаний отдельные страны Содружества Независимых Государств продвинулись значительно вперед, существенно обновив свою нормативно-правовую основу. К их числу относится Республика Казахстан. Проведенное исследование нормативного закрепления и организации воспитательной работы с осужденными по казахстанскому и российскому законодательству, опрос практических работников выявили достоинства и недостатки нормативного обеспечения и правоприменительной практики. Это позволило наметить дальнейшие пути совершенствования правового регулирования воспитательной работы с осужденными в сторону сближения с международными стандартами. Уголовно-исполнительное законодательство двух стран во многом совпадает, однако в Казахстане вопросы воспитательной работы находят свое правовое закрепление не только на уровне Уголовно-исполнительного кодекса, но и в специальных актах. К преимуществам казахстанского законодательства следует отнести: четкое обозначение задач, направлений, форм и методов воспитательной работы; усовершенствование механизма применения мер поощрений и взысканий; определение степени поведения осужденных; привлечение Службы пробации в оказании социально-правовой помощи готовящимся к освобождению осужденным; наличие в числе субъектов воспитательной работы добровольных организаций осужденных. В остальном, организация и проведение воспитательной работы с осужденными совпадают. Основой организационного построения исправительного учреждения является отряд, начальники которых перегружены выполнением задач, непосредственно не связанных с осуществлением исправительно-воспитательного процесса. Учитывая опыт Республики Казахстан, предлагается внести изменения в Уголовно-исполнительный кодекс Российской Федерации, в части формулирования понятия воспитательной работы через ее задачи; уточнения норм, касающихся направлений, форм и методов воспитательной работы. В Положении об отряде осужденных исправительного учреждения необходимо изменение объема функциональных обязанностей начальника отряда: установление запрета (ограничения) на привлечение начальников отряда к выполнению несвойственных для них функций; переведение в разряд прав вмененную начальнику отряда обязанность участия в проведении проверок наличия лиц, содержащихся в исправительном учреждении, разводов (съемов) их на работу (с работы), присутствия при проведении обысковых мероприятий, приеме осужденными пищи в столовой, выдаче им посылок (бандеролей), передач, продаже продуктов питания и предметов первой необходимости, ведении телефонных переговоров.

Ключевые слова: воспитательная работа с осужденными к лишению свободы, уголовно-исполнительное законодательство, Российская Федерация, Республика Казахстан. 
International penitentiary journal, 2019, vol. 1(1-3), iss. 2

\section{Information about authors / Сведения об авторах}

Aleksey Nikolaevich Siryakov, PhD (Law), associate professor of the penal law department, Academy of FPS of Russia, Ryazan, Russian Federation, e-mail: 643350@mail.ru.

Алексей Николаевич Сиряков, кандидат юридических наук, доцент кафедры уголовно-исполнительного права, Академия ФСИН России, г. Рязань, Российская Федерация, e-mail: $\underline{643350 @ \text { mail.ru. }}$

El'dar Hasanovich Abishev, master student of the Kostanay Academy of the Ministry of Internal Affairs of the Republic of Kazakhstan after Shyrakbek Kabylbayev, Kostanay, Republic Of Kazakhstan, e-mail: popovich.82@mail.ru.

Эльдар Хасанович Абишев, магистрант Костанайской академии МВД Республики Казахстан имени Шракбека Кабылбаева, г. Костанай, Республика Казахстан, e-mail: popovich.82@mail.ru.

\section{Recommended citation / Для цитирования}

Siryakov, A. N. \& Abishev, E. H. 219, 'Legislation on educational work with prisoners in Russia and Kazakhstan', International penitentiary journal, vol. 1(1-3), iss. 2, pp. 84-98, doi: 10.33463/2712-7737.2019.01(1-3).2.084-098.

Сиряков, А. Н., Абишев, Э. Х. Законодательство о воспитательной работе с осужденными к лишению свободы в России и Казахстане / А. Н. Сиряков, Э. Х. Абишев // Международный пенитенциарный журнал. - 2019. - Т. 1(1-3), № 2. C. 84-98. - DOI : 10.33463/2712-7737.2019.01(1-3).2.084-098. 


\section{Introduction}

In modern Russian and Kazakhstan society, the prevailing opinion is about the activities of the law enforcement system to combat crime as exclusively punishing. It is often overlooked that the law enforcement agencies also have an educational function. This work is of particular importance in the context of the execution of criminal penalties in the form of deprivation of liberty. Thus, in the Concept of development of the penal system of the Russian Federation until 2020, adopted by the order of the Government of the Russian Federation No. 1772 on 14.10.2010, indicates that one of its tasks is to develop forms of educational work with convicts. The Concept also defines the ways of improving educational work: orientation to the involvement of convicts (sentenced to deprivation of liberty) in work, the acquisition of a profession or retraining; development of educational work in the direction of ensuring the resocialization of convicts, the development of their basic social functions; its implementation is subject to the interaction of correctional officers with each other, the involvement of representatives of the executive authorities, civil society institutions; planning, organization and conduct of educational activities in correctional institutions aimed at the formation and development of convicts' desire for socially useful activities, compliance with the requirements of the laws and the rules of conduct adopted in society. Such provisions are contained in the Concept of the legal policy of the Republic of Kazakhstan for the period from 2010 to 2020 , established by the decree of the President of the Republic of Kazakhstan on 24.082009 No. 858 , which provides the need for further development of the content, forms and methods of correctional and educational impact on convicts on the basis of the principle of individualization of punishment execution.

In connection with the same desire of States to reduce the punitive element in the execution of punishment, the purpose is to compare the features of legal regulation of the organization and conduct of educational work with prisoners in the Russian Federation and the Republic of Kazakhstan. To do this, we will analyze the current penal legislation of the two countries in terms of educational work with prisoners, as well as the practice of its organization. We will also find out the opinion of the chiefs of units on issue to their satisfaction of regulatory requirements. Thus, we will see the similarities and differences, advantages and disadvantages of educational work in places of detention.

\section{Results and their discussion}

The legal regulation of the educational work of the two countries is based on the Penal legislation, which has a significant similarity (Potapov, A. M. \& Kuz'min, S. I. 2017). This is due not only to the general legal framework that has been in force for a long time on the territory of the USSR and the Union Republics, but also to the adoption in St. Petersburg (on November 2, 1996) at the eighth plenary session of the CIS inter-parliamentary Assembly of the recommendatory legislative act - the Model penal code. This document was the basis for the preparation and adoption of national penal codes of independent States. On January 8, 1997 the Penal code of the Russian Federation (hereinafter - the PC of the Russian Federation) appeared, and eleven months later, on December 13, 1997 - the Penal code of the Republic of Kazakhstan. These documents are not fundamentally different from each other at the time of their adoption. However, further legal construction of states became different and went on the way of convergence of national norms with international standards. In the Republic of Kazakhstan, this process resulted in the adoption of a new Penal code on July 5, 2014 (hereinafter - the PC of the Republic of Kazakhstan).

Regulating educational work with convicts to imprisonment, the PC of the Republic of Kazakhstan and the PC of the Russian Federation coincide in many ways. However, the PC of the Republic of Kazakhstan has certain advantages, although it is not devoid of certain shortcomings. Thus, both documents 
provide for the Chapter «Educational impact on convicts to imprisonment» (Chapter 20 of the PC of the Republic of Kazakhstan, Chapter 15 of the PC of the Russian Federation), which does not contain a definition of educational work. Article 109 of the Code of criminal procedure reproduces the provisions of part 1 of article 9 , which defines the category of «correction» and adds a provision on improving the educational and cultural level of convicts. Other articles of the document stipulate the need for educational work with different categories of convicts: the article 56 - with convicts sentenced to restriction of freedom, the article 165 - with convicted servicemen. Article 124 of the PC of the Republic of Kazakhstan states that educational work with convicts is aimed at their correction, formation and strengthening of the desire to comply with the requirements of the laws, work and other socially useful activities, improving the educational and cultural level, participation in programs aimed at social and legal assistance to convicts. In this regard, the PC of the Republic of Kazakhstan seems more logical, as the definition of correction, established in paragraph 10 of the article 3 as the formation in the convict of law-abiding behavior, positive attitude to the individual, society, work, norms, rules and ethics of behavior in society, can be considered common in relation to educational work, as a particular one of the means of correction. Another difference is that the content of educational work includes participation in programs aimed at social and legal assistance to convicts.

There are questions when determining the place of educational work among other basic means of correction. According to the text of the PC of the Republic of Kazakhstan, among the means of correction is educational impact, there is a Chapter of the same name, which contains an article on educational work, work on social adaptation and psychological assistance, voluntary organizations of convicts, education. Therefore, it is not clear at all whether educational work is a means of correction or not.
Enumerating means of correction, educational impact is on the second place, and regime is on the first place, at the same time, the content of educational work is revealed after the regime, public service, and education. In accordance with the provisions of article 9 of the $\mathrm{PC}$ of the Russian Federation educational work among the main means of correction is on second place, and regime is on the first place. According to article 109 of the PC of the Russian Federation, only educational work, unlike other means of correction, is directly aimed at the correction of convicts. According to the legislator, educational work, forming in convicts a respectful attitude to the person, society, work, norms, rules and traditions of human society, should determine the direction of the use of other means of correction within the regime. The structure of the Special part of the PC of the Russian Federation, in particular section IV, the rules of which regulate the execution of the penalty of imprisonment, violates this logic. Questions of educational work are revealed by the legislator after the regime, labor, vocational education and training. In addition, Chapter 15 of the PC of the Russian Federation is built in such a way that it covers the rules governing education, the Institute for the application of incentives and penalties. In this part, both documents do not have the internal logic inherent in the Correctional labor code of the RSFSR (adopted in 1970), in which the main means of correction were consistently fixed.

The tasks of educational work are not clearly formulated in normative legal acts. Realizing the purpose of correction, its main means are created to solve particular problems. Regarding educational work, the Russian legislator does not directly specify them, but the text of the PC of the Russian Federation allows us to formulate the following: improving the educational and cultural level of convicts; correction, that is, the formation of respect for the person, society, work by the convict, norms and rules of the human living (Article 109 of the PC of the Russian Federation); preparation of the convict 
for release (Article 180 of the PC of the Russian Federation), social adaptation (Article of 181 the PC of the Russian Federation). In the PC of the Republic of Kazakhstan, the tasks of educational work are specific and expressed mainly in Article 124 of the PC of the Republic of Kazakhstan. These include: the formation and strengthening of the desire to comply with the laws, work and other socially useful activities; improving the educational and cultural level; participation in programs aimed at social and legal assistance to convicts; preparation for release (Article 166 of the PC of the Republic of Kazakhstan). Article 125 of the PC of the Republic of Kazakhstan specifies the main forms of work on social adaptation of convicts: 1) development of individual programs for work with convicts; 2) development, organization and implementation of programs aimed at social and legal assistance to convicts; 3 ) involvement of state bodies, local executive bodies and the public in social and legal assistance to convicts; 4) promotion of positive social relation of convicts; 5 ) provision of assistance to released persons.

In both documents it is noted that educational work is carried out with reliance on the personality. Thus, in the article 109 of the PC of the Russian Federation and 124 of the PC of the Republic of Kazakhstan it is recorded that the educational approach takes into account the individual peculiarities of the personality, the nature of the convicts and circumstances of the crime.

In order to involve convicts in educational activities, Russian and Kazakhstan penal legislation has established certain types of incentives. This means that the participation of convicts in educational activities is taken into account when: applying to them measures of encouragement and punishment (Russia, Kazakhstan); determining the degree of correction (Russia); assessing the behavior of convicts (Kazakhstan).

The new PC of the Republic of Kazakhstan improved the mechanism of applying incentives and penalties to convicts, taking into account the principle of humanism. Thus, the legislator excluded from the system of penalties such measures as the placement of women and juveniles in disciplinary detention and solitary confinement. Also in the PC of the Republic of Kazakhstan provides a number of measures aimed at preventing corruption from the administration of institutions. For example, the law of the use of penalties and incentives in respect of convicts are presently given only to heads of agencies and their deputies. Previously, such powers were provided for the chiefs of units.

Determining the degree of correction has long been a problem for the Russian penitentiary practice. There are no clear criteria and procedures for determining this degree. The PC of the Russian Federation contains mention of malicious violators of the established order of serving of punishment (Article 74, 78, 97, 116 the PC of the Russian Federation); negatively characterized convicts (Article 140 the PC of the Russian Federation); positively characterized convicts (Article 78, 96, 113, 128,175 the PC of the Russian Federation); convicted servicemen characterized by exemplary behavior, conscientious attitude to military service and labor (article 166 of the PC of the Russian Federation). There is no systematic list of degrees of convicts' correction, which would reflect the gradual change of personality and the dynamics of correction.

An assessment of the convicts' behavior is provided by article 95 of the PC of the Republic of Kazakhstan. It is a clarification of the degree of convicts' behavior: compliance with the rules of the internal order of institutions; attitude to work and study; participation in educational activities; participation in programs aimed at social and legal assistance to convicts; membership in the voluntary organization of convicts; taking measures to compensate the harm caused by the crime. There are three degrees of behavior for positively characterized convicted persons and three for the negatively characterized convicted persons. 
The title of the article 110 of the PC of the Russian Federation «Basic forms and methods of educational work with convicts» does not correspond to its content. Part 1 of this article refers to moral, legal, labor, physical or other education that contributes to the correction of convicts; part 2 specifies the requirement of differentiated organization of educational work, taking into account the type of correctional institution, the term of punishment and conditions of detention. Individual, mass and group forms of implementation of educational work on the basis of psychological and pedagogical methods are represented. It becomes unclear what to consider as forms of educational work: individual, group and mass events or moral, legal, labor, physical and other education. Thus, there is no sense in the instruction of the legislator on psychological and pedagogical methods of educational work for law enforcement officers.

This problem was avoided by the Kazakhstan legislator, writing in Article 124 of the PC of the Republic of Kazakhstan that the institutions carry out moral, social, legal, labor, physical and other types of education (part 2) in individual, group and mass forms with the use of psychological and pedagogical methods (part 3). At the same time, the order of the Ministry of Internal Affairs of the Republic of Kazakhstan dated August 13, 2014 № 508 «On approval of the Rules of educational work with convicts to imprisonment» fixed that moral education is aimed at the formation of convicts moral and ethical attitudes, the formation of each convict's ability to regulate their behavior in society without daily external control; sociolegal education - to obtain ideas about the nature of the relationship between the citizen and the state, knowledge about the rights and obligations of convicted prisoners in places of deprivation of liberty, the belief in the necessity of legal compliance, awareness of social danger of the crime; aesthetic education - to develop the understanding of the beauty of nature, art, literature, painting, contributing to the education of the convicted person aesthetic taste and friendly attitude to environment; labor education is aimed at the development of convicts' labor skills, the acquisition of a profession necessary for employment after release; physical education - to maintain the convicts' physical health in places of detention and leisure; psychological education - to study the laws of mental activity of a person serving a sentence, the destruction of his criminal stereotype, the study of the personality of the convict, the main factors affecting him in the process of re-education. As an example, it is possible to point to the following developed materials: «1000 business ideas for small and medium-sized businesses», "14 success stories of prisoners», etc. The document also establishes the main difference between the forms of educational work. Thus, in paragraph 10 it is recorded that the individual work with prisoners is based on peculiarities of the personality of the convicted person, focus on successful adaptation to life at liberty, in accordance with the programme of work with convicts, designed for the whole period of his stay in the institution based on the recommendations of a psychologist, and is divided into four main periods: the period of adaptation to get used to new conditions of life; the period of the emergence and development of interests in the new conditions of life; the period of a combination of external influences with self-education; the period prior to the release of the convict. On the basis of the programme of work with the convicted person, the head of the unit shall make an individual plan of educational work for each period of the convicted person's stay in the institution. Group and mass forms of educational work with convicts (classes, lectures, meetings, debates, competitions, arts festivals, sports events, participation in voluntary organizations, psycho-diagnostic, psycho-correction, psychoprophylactic and advisory work) involve the conduct of educational work in small and large groups.

Thus, the external design of the content of educational work is an individual, group 
or collective (mass) form. The main criterion for their classification should be the method of educational influence directed at the person, group or all convicted persons of the correctional institution. In this regard, individual educational work is an observation of the convicted person behavior, the study of its relationship with the social environment to select the optimal path of educational impact. Group educational work is aimed at studying the social orientation of the group of convicts, the peculiarity of its status-role structure, inter-group activity, stability of relationships and conflictness. Mass educational work is associated with the organization of general educational activities and less personified.

In detail, the issues of educational work with convicts are regulated in subordinate normative acts relating to the activities of the penitentiary system of Russia and Kazakhstan. In our opinion, all existing subordinate legislations in this area can be divided into three groups of documents: a) creating a legal basis for the educational work organization and empowering the subjects of its implementation; b) forming the material basis of the educational units in correctional institutions; c) aimed at improving educational work with prisoners. In the Russian Federation and the Republic of Kazakhstan there are both policy documents focused on updating the legislation and normative-legal acts regulating different spheres of correctional institutions activity: education, religious sphere, internal regulations, etc. However, Kazakhstan has a single order of the Ministry of Internal Affairs of the Republic of Kazakhstan (adopted on 13.08.2014) No. 508 «On approval of the rules of educational work with convicts», which explains in detail the content of educational work with convicts held in different conditions of serving punishment, newcomers, convicts preparing for the release, juveniles, persons sentenced to life imprisonment, etc.

As you can see, the Penal legislation of both countries, regulating educational work with convicts, requires further improvement. We believe that it is necessary to consolidate in the legislation the general issues of educational work: its concept, objectives, principles, forms and methods. The Kazakhstan legislator has already taken this path and outlined the essence and concept of educational work. The used phrases there are more preferable. In the $P C$ of the Russian Federation it is possible to propose a similar definition instead of repeating in the current version of the concept of "correction», which is not related to the title of the article (article 109 of the PC of the Russian Federation). We propose to formulate the concept of educational work through its objectives.

It seems appropriate to clarify the rules of the $\mathrm{PC}$ of the Russian Federation concerning the basic forms and methods of educational work: the content of article 110 should correspond to its name. From the current version of the article it is necessary to remove the rules not related to the title of the article: on the directions of educational work (part 1) and material support of the organization of educational work (part 3). The new version of the article should not only list, but also reveal the forms of educational work, as well as reflect the principle of differentiation and individualization of the execution of punishment, according to which various forms and methods of educational work should be used. Due to the fact that the current law contains this principle in Article 109 and 110 of the PC of the Russian Federation, we propose to combine it into one article: «1. Educational work with convicts is organized in a differentiated manner, taking into account the type of correctional institution, the term of punishment, the conditions of detention, the individual characteristics of the person, the nature of the convicts, the circumstances of the crimes committed by them in individual, group and mass forms.» In the second part of this article it is necessary to fix difference of forms of educational work from each other and in the third - to list the main psychological and pedagogical methods: «2. Individual educational work is organized and conducted with an individual convict. Group educational 
work is organized and conducted with different groups of convicts. Mass educational work is the organization and conduct of common educational activities. 3. Individual, group and mass educational work is carried out on the basis of psychological and pedagogical methods of persuasion, stimulation, coercion and others".

Among the organizers of educational work with convicts in Russia and Kazakhstan it is possible to distinguish the following: staff of institutions executing punishment, public associations (article 23 of the PC of the Russian Federation, paragraph 7 of the Order of the Ministry of Internal Affairs of Kazakhstan No. 508), parents, persons replacing them and relatives of convicts (article 142 of the PC of the Russian Federation), committees of parents, citizens, boards of trustees, trade unions, labor collectives (paragraph 7 of the Order of the Ministry of Internal Affairs No. 508), local governments (article 165 of the criminal code).

In accordance with the current legislation of Russia and Kazakhstan, the general management and control over the organization of educational work of the staff of the institution is carried out by the head of the institution. He provides involvement in the organization and conduct of educational work of the whole staff of the institution. He is a tutor himself.

Management of the organization and conduct of educational work is entrusted to the deputy head of the correctional institution for personnel and educational work. In Kazakhstan -the deputy head of the institution for educational work. He is personally responsible for the organization and effectiveness of educational work; ensures the interaction of the staff of the institution in this direction, attracts to the educational work of representatives of public and religious associations, the organization of various forms of ownership; provides methodological guidance of educators, promotes training of employees in the basics of law, pedagogy, psychology, social work, forms and methods of educational work.
The heads of the department for educational work with convicts directly organize educational work in the institutions in Russia and Kazakhstan. They plan educational activities in the institution, monitor the activities of the chiefs of the detachments, provide methodological and practical assistance, organize rational employment of convicts in their free time, supervise the leisure section of the convicts and conduct individual educational work with them.

The leading role in educational work with convicts in the unit belongs to the head of the unit, which has a significant number of functional duties. We propose to consider them in the form of three groups: a) ensuring the organization and conduct of educational work in the unit; b) directly aimed at the implementation of educational work in the unit; c) not directly related to the implementation of educational work in the unit (Siryakov, A. N. 2007).

To the functions ensuring the organization and conduct of educational work in the unit, we will relate the organization of own activities (individual planning, work planning with convicts work in the unit); documentation (filling of the diaries of individual educational work with convicts, logging, work with the personal files of prisoners for the preparation of various documents, preparation of reports); participation in the work of collegial bodies (administrative Commission of the methodological Council, Council of educators of the colony, the holding of meetings of the Board of educators of the squad; interaction with the management, staff of departments and services of the institution (participation in meetings held by heads of the institution, coordination of various documents, exchange of information, participation in the conduct of official investigations, etc.).

The functions directly aimed at the implementation of educational work in the unit include the following: a) work with the staff of convicts (preparation for the meeting of the unit Council, various activities of sections, holding a meeting of convicts of the unit, classes with convicts, organization of visual propaganda, 
work in the school of preparation for the release of convicts, organization of group work, etc.); b) individual educational work with the convict (study of personality: conversations with newly arrived convicts, with hard-to-educate, persons who are on preventive registration, work with offenders of the detention regime, with convicts who are in the punishment cell, a room of a chamber type, a safe place, reception on personal issues), clarification of rights and obligations, the solution of issues of material and domestic support, etc.; B) interaction with the public (representatives of public organizations and associations, religious denominations, meetings and conversations with relatives of convicts, etc.).

Functions, that are not directly related to the implementation of educational work in the unit, are the following: participation in regime activities (monitoring of food intake, workplace, checking the availability of convicts, sanitary conditions of the premises of the unit, inspection of the appearance of convicts, presence at the conclusion of the work of convicts, control of getting parcels, telephone conversations, participation in the conduct of search activities, organization of work on the improvement of the dormitory and the adjacent territory of the unit, etc.); service on duty, as part of the operational group, presence at school (training and consulting point), vocational school; service and other training.

Thus, the organization of work of the head of the unit noted the following: the availability of a wide range of duties, including not related to the organization and carrying out of educational work with convicts in his unit, the lack of order and level of its interaction with workers of other services, the lack of real power and authority in relation to the staff and convicted persons (including the right incentives and penalties), etc. In addition, the head groups are forced to work with a significant number of prisoners in the units.

Normative legal documents create a legal basis for participation in educational work with convicted representatives of other departments and services of the institution. The staff of the security department, operational department and duty shifts are assigned to conduct educational work both directly (individual, group and collective educational work by convicts) and indirectly, through proper protection of facilities and isolation of convicts, organization of internal regulations, work on crime prevention. The employees of the centers of labor adaptation of convicts also carry out direct activities aimed at solving social problems related to the labor adaptation of convicts, and indirectly affect the educational work through the provision of labor employment of convicts. In the Republic of Kazakhstan, special attention is paid to the work of psychologists. Their task is to conduct a study of the personality of the convict; to find out interpersonal relationships among convicts; to investigate the causes and motives of interpersonal and inter-group conflict situations; to develop recommendations for the prevention of violations of the established order of serving of punishment and to carry out consulting work with the management and staff of the institution on questions of convicts behavior tactics; to organize a study of the character characteristics of the individual on applications for a psychodiagnostic examination of the convict. In paragraph 78 of the order of the Ministry of Internal Affairs of Kazakhstan No. 508 these objectives have the specific content: diagnostics of individual psychological peculiarities of the personality of convicted persons, examination and correction of individual and group behavior, the study of the psychosocial processes in the environment of prisoners, the prediction and prevention of negative phenomena in the places of deprivation of liberty; providing psychological assistance to convicts in adapting to the conditions of isolation, social environment, detention regime, in overcoming crisis and stress situations, optimizing interpersonal relations, in preparation for release and resocialization. Diagnostic, consultative, psycho-corrective, predictive, pechoroilychsky, educational, and research functions of psychologists are provided. Their powers are defined. 
The staff of the correctional institution also includes the staff of the secondary school (professional school) at the correctional institution. It takes part in educational work, organizes extracurricular and extracurricular activities of convicts. In addition to group work, teachers conduct individual work. The teaching staff is also involved, as members of the Board of educators, chiefs over hard-to-educate convicts, the organizers of the sections of the squad and the colony.

The methodical Council of correctional institutions, groups of tutors act as bodies responsible for methodological leadership of the organization of the correctional process. The methodical Council consists of teachers, employees of other services and parts of the institution, employees of labor adaptation centers, teachers of secondary school and vocational school at the institution, representatives of the public. The methodical Council defines the direction of educational work in correctional institution. It makes recommendations on improving the efficiency of educational work with convicts, on more effective application of penalties and incentives to certain categories of convicts, parole, etc. At its meetings reports on the dissemination of best practices of individual educators are heard, elimination of errors and shortcomings in the practice of education are discussed.

The Board of educators of the unit includes: the head of the unit, the staff of the correctional institution with the skills of educational work, teachers of secondary school and vocational school at the institution (in the Kazakhstan Republic - teachers of secondary school and vocational college, educational advisory points), representatives of the public. The main functions of the Board of educators of the unit are: to assist the head of the unit in the implementation of the plan of educational work with convicts; to study the behavior of convicts in order to improve the effectiveness of individual educational work; to assist in determining the methods of work with difficult convicts; to strengthen the rule of law. The content of the activities of the Board of educators is determined by the level of training of the head and the member structure of the Council.

In the Republic of Kazakhstan, the newly formed probation Service takes part in the implementation of educational work in respect of convicts who have 1 year left before their release. According to p. 44 of the Order of the MIA of the Republic of Kazakhstan No. 508, it organizes together with the staff of correctional institution social and legal assistance. For this purpose, the convict is made up of an individual program, which includes: data of the pre-trial report (if any), developed by the probation Service at the stage of pre-trial probation; materials characterizing the behavior of the convict during his stay in the institution of the penal system; information on compensation and (or not) of claims by the person preparing for release; about social relations of the convict prepared for release, the state of his health, the level of education, labor skills, awareness of legal mechanisms of implementation of the rights and freedoms, and also other information necessary for correction of social behavior and successful social adaptation; the specific actions directed on social and legal assistance to the convict prepared for release; the planned actions for social and legal assistance and household and employment of the convict after his release.

Public associations provide significant assistance in the organization and conduct of educational work. It includes labor collective councils, trade union organizations, boards of trustees, religious organizations, etc. Representatives of various public charitable organizations and religious associations, as well as the boards of trustees of the penitentiary system formed in recent years, are the most active among them. Along with the provision of charitable assistance, the Central Board of Trustees and its regional branches carry out educational work: cultural, educational, sports and other mass events, organizing meetings of convicts with famous people, providing legal assistance, etc. 
In the Republic of Kazakhstan, convicts themselves are active subjects of educational work. Voluntary organizations of convicts (Article 126 of the PC of the Republic of Kazakhstan) are created to promote the correction of convicts in institutions on a voluntary basis and work under the supervision of the administration of the institution. Paragraph 58 of the order of the MIA of the Republic of Kazakhstan No. 508 formulates the main tasks of voluntary organizations of convicts. It includes the formation of healthy relationships among convicts, the promotion of useful initiatives for society and influencing the correction of convicts, participation in the organization of work, life and leisure.

Participation in them is, along with the presence of incentives and the absence of penalties for a certain period of time, indicators of correction of the convicted person. It should be noted that the PC of the Russian Federation was known until 2011 a similar form of Association of convicts - amateur organizations.

Meetings of voluntary organizations of convicted persons shall be held at least once a quarter and shall be formalized by a protocol. At the meeting, regardless of the nature of the issues discussed, there is a representative of the administration of the institution. In paragraph 59 of the order of the Ministry of Internal Affairs of Kazakhstan No. 508 provides the structure of the voluntary organizations: the section of leisure and self-education; industrial; sanitary and hygienic and other areas of prisoners' interest. The section of leisure and self-education takes part in the organization of leisure of convicts, sports, cultural, social, educational and other activities. The production section involves convicts into the workforce, improves the quality of work performed and manufactured products, makes suggestions to the staff about using of convicts labor, together with the staff inspects the compliance with safety regulations; assists in the dissemination of best practices, innovation and inventiveness. The sanitary and hygienic section promotes the observance of personal hygiene and industrial sanitation by convicts; together with medical officers, it conducts raids to check the sanitary condition of residential, communal and household premises of units and the territory of the institution; produces sanitary bulletins, wall newspapers and radio broadcasts.

The collective councils of positively proved convicts groups are created in correctional institutions.

The Church has been actively involved in the moral and religious education of convicts recently. The relations between the Russian Orthodox Church and the penitentiary system are based on the order of the Ministry of justice of Russia No. 67 «On approval of the requirements for the content of agreements on cooperation between the Federal penitentiary service and the territorial bodies of the penitentiary system and duly registered centralized religious organizations» (adopted on 21.03.2016). It defines a list of designated buildings for religious ceremonies, a list of objects of worship and religious literature, a schedule of religious events, information on the priests, the rights and obligations of a religious organization, as well as institutions of the penal system. In Kazakhstan, the work of religious associations is organized on the basis of the order of the Ministry of Internal Affairs No. 503. It states that the administration of the institution, taking into account the proposals of religious associations, approves the visits schedule for representatives of religious associations for the coming calendar year. This schedule is agreed with the head of the relevant religious association and is valid for 1 year. A copy of this schedule is placed in each unit (prison cell) of the correctional institution. The administration of the institution provides premises for meetings of convicts with priests. This room is provided with the necessary equipment for non-religious purposes (table, chairs, etc.). If it is necessary to listen to and demonstrate materials on religious topics, audio and video equipment is installed in the room. Religious literature and other information materials of religious 
content, religious objects are stored in the library of the correctional institution. If necessary, they are used during religious ceremonies when representatives of religious associations visit a correctional institution. Convicted persons use them in the reading room of the library at a certain time of the day.

The Church in Russia provides spiritual help to persons serving sentences in places of deprivation of liberty, takes part in the construction of churches, chapels, prayer rooms in correctional institutions, provides believers with spiritual literature and religious objects, assists in the training of specialists among the employees of the penitentiary system to work with believers held in pretrial detention facilities and serving criminal sentences in correctional institutions.

In order to ensure spiritual and moral influence on the convicts by the priest, a certain practice has developed. In each region, a person responsible for the spiritual care of convicted persons (assistant to the head of the territorial authority for religious affairs) is appointed among the priests.

Parents, guardians, relatives and close friends of convicted persons also act as subjects of educational work in Russia and Kazakhstan.

Improving the organization of educational work with convicts in a correctional institution is associated with attempts to reform the detachment. However, in our opinion, the existing detachment system is quite enough to solve the tasks, it only requires some adjustments associated with the redistribution of a number of powers. Our conclusion is confirmed by the analysis of the results of the survey. We asked the chiefs of the detachments three questions: what additional functions they would like to receive, what functions they would transfer to the staff of other units of the institution and whether the Regulation on the detachment of convicts of the correctional institution requires revision. The survey revealed that the majority of respondents (85\%) would not like to add additional powers to the existing ones. Others consider it necessary to obtain certain powers: the right to place the convict in a punishment cell, a written announcement of the type of encouragement and punishment, participation in the decision on parole. Respondents were more active on the transfer of functions to other divisions and services. One third of the respondents insist on the need to transfer a number of functions to other departments: public services of convicts - to the department of intendant and economic support; participation in routine activities (during searches, presence at the placement of the convict in the punishment cell, room type, meal, when sending to work and removing from work, delivery of parcels, parcels, telephone conversations) - to the security department, production department; duty in the residential or industrial zone - to the duty service; implementation of procedural actions (carrying out official investigations on the facts of violations, preparation of various documents on these facts, etc.) - to the operational department. Thus, it is not necessary to fundamentally change the officer system, but to optimize the activity of the head of the detachment, to exclude the head of the group in activities not related to the process of convicted persons correction. According to the survey, the majority of respondents are against the proposal to introduce additional staff units in the detachment, if the number of the detachment is up to $50-70$ people. In the rest, such a unit is in demand. At the same time, various positions were called: deputy chief of the detachment (inspector) in the amount of one person or depending on the directions (labor, regime, office work, etc.), psychologist, and social work specialist. The study of the question of the functional duties of the head of the unit and the photographing of the working day during the working week led to the conclusion that it was necessary to amend the Regulations on the detachment of convicts in the correctional institution. The essence of our proposed novels is as follows. Firstly, it 
is necessary to clearly establish the rule on the prohibition of involving the chief of the detachment to work not in his detachment. In the current provision it is specified: «Involvement of chiefs to the activity which is not connected with implementation of requirements and norms of the Penal legislation, normative legal acts of the Ministry of Justice of the Russian Federation or this Provision is not allowed». We suggest to state this norm as follows: «Involvement of the chief of squad in the activity which is not relating to the organization and carrying out of social, psychological and educational work with convicts in the squad assigned to it is not allowed». Secondly, it is required to make changes to the section establishing the rights and duties of the chief of group. The transfer to the category of rights imputed to the chief the obligation to participate in inspections of the presence of persons held in a correctional institution, taking them to work (from work), their presence during searches, mealtime in the dining room, getting of parcels, transfer, sale of food and basic necessities, telephone conversations. We also propose to provide the methods of stimulation and coercion used by the head of the unit with the right to apply to the head of the institution for the application of penalties and incentives to convicts, since in the current Provision there is a vague phrase on the proposal and participation of the head of the unit in the consideration of issues related to the application of incentives and penalties.

\section{Conclusion}

The conducted comparative legal study of educational work with convicts sentenced to deprivation of liberty in Russia and Kazakhstan allowed us to conclude that the penal legislation of the Republic of Kazakhstan in the matter of legal regulation of educational work with convicts is preferable.

Firstly, the Kazakhstan legislator formulated the concept and content of educational work, revealed its types and forms. Secondly, the Republic of Kazakhstan has a special subordinate legislation defining the basis for the organization and conduct of educational work with convicts. However, the PC of the Republic of Kazakhstan still has some disadvantages inherent in the PC of the Russian Federation. In addition, the organization and conduct of educational work in Kazakhstan is not different from the Russian penitentiary practice, since it is provided by almost identical organizers of the educational process as the main object of educational activities. The difference can be seen in the preservation as subjects of educational work of convicts themselves within the framework of voluntary organizations of convicts, the involvement of probation officers in the educational work at the final stage of serving a criminal sentence.

Thus, the comparison of the penal legislation of the two countries will not only allow to learn the specifics of educational work with convicts in them, but also to identify ways to improve the legal regulation in the direction of convergence with international standards.

\section{References}

Potapov, A. M. \& Kuz'min, S. I. 2017, 'About educational influence on convicts in the Russian Federation and the Republic of Kazakhstan: comparative legal aspect', in Golodov P. V. (ed.), Criminal punishment in Russia and abroad: problems of appointment and execution (to the 10th anniversary of the adoption of the European prison rules): collection of materials of the International scientific and practical conference, in 2 vols, pp. 241-246, Vologda.

Siryakov, A. N. 2007, 'Organization and conduct of educational work by the head of the unit in the correctional institution', Man: crime and punishment, no. 1, pp. 46-49.

\section{Библиографический список}

Потапов А. М., Кузьмин С. И. О воспитательном воздействии на осужденных в Российской Федерации и Республике Казахстан: сравнительно-правовой аспект // Уголовное наказание в России и за рубежом: проблемы назначения и исполне- 
International penitentiary journal, 2019, vol. 1(1-3), iss. 2

ния (к 10-летию принятия Европейских пенитенциарных правил) : сб. материалов Междунар. науч.-практ. конфр. : в 2 ч. / под общ. ред. П. В. Голодова. Вологда, 2017. C. 241-246.
Сиряков А. Н. Организация и проведение воспитательной работы начальником отряда осужденных исправительного учреждения // Человек: преступление и наказание. 2007. № 1. С. 46-49. 